Check for updates

Cite this: RSC Adv., 2017, 7, 18217

\title{
Selective turn-on near-infrared fluorescence probe for hypoxic tumor cell imaging $\dagger$
}

\author{
Chen Jin, ${ }^{a}$ Qiumeng Zhang ${ }^{\mathrm{a}}$ and Wei Lu (D) *ab
}

\begin{abstract}
Hypoxia is a typical feature of solid tumors. To detect hypoxic tumor cells, we designed new selective turnon probes by conjugating (1-methyl-2-nitro- $1 \mathrm{H}$-imidazol-5-yl)methanol to the near-infrared fluorescence probe DCPO through an ether linkage and bis-carbamate linkage specifically. The proposed activation mechanism was demonstrated through the nitroreductase and cytochrome P450 assays in vitro. However, two probes revealed different hypoxia selectivities when evaluated on H460, HeLa and A549 cell lines. The hypoxia selectivity of IOD was higher than that of IND. The probe IOD (containing the ether linkage) was considered to be a promising hypoxia-selective fluorescent probe.
\end{abstract}

Received 5th February 2017

Accepted 20th March 2017

DOI: 10.1039/c7ra01466j

rsc.li/rsc-advances emission tomography). However, the disadvantage that a radioactive tracer must be injected into patients is the main problem with PET.

Near-infrared (NIR) fluorescent dyes have been widely used for monitoring biological processes in cells and organisms. ${ }^{20-28}$ In general, NIR fluorophores emit fluorescence in the range of 650$900 \mathrm{~nm}$. Compared with PET, NIR probes possess the advantages of minimal photo-damage to biological samples, deep tissue penetration, and low background auto-fluorescence. (E)-2-(2-(4Hydroxystyryl)-4H-chromen-4-ylidene)malononitrile (DCPO) and its derivatives are photostable and widely used in the detection of cathepsin B, hydrogen peroxide, and GLUT-1..$^{29-34}$

Several works have reported the targeting of hypoxic tumors with turn-on fluorescent probes containing a bioreductive nitro group or azo group. ${ }^{35-42}$ However, (1-methyl-2-nitro-1 $H$-imidazol5-yl)methanol, which was applied in the clinical hypoxiaactivated prodrug evofosfamide (TH-302) ${ }^{43}$ and considered an effective bioreductive molecule, has been sparingly used in the development of hypoxia imaging. Recently, Grimm reported a dual-input fluorogenic probe using (1-methyl-2-nitro- $1 \mathrm{H}$-imidazol-5-yl)methanol. ${ }^{44}$ Though the probe was demonstrated to be
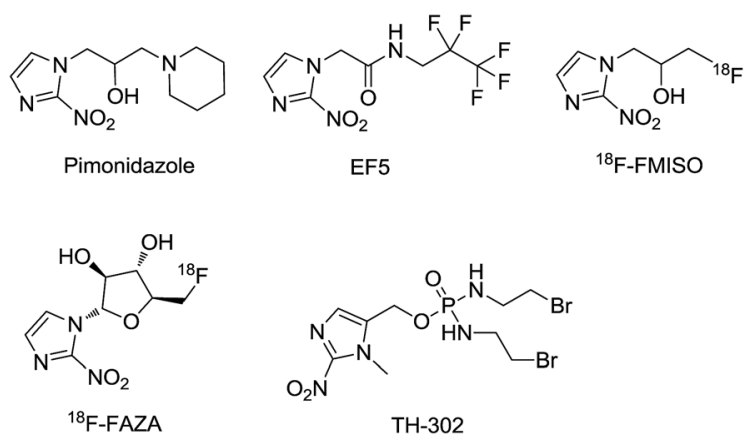

Fig. 1 Chemical structures of pimonidazole, EF5, ${ }^{18} \mathrm{~F}-\mathrm{FMISO},{ }^{18} \mathrm{~F}-\mathrm{FAZA}$ and evofosfamide (TH-302).
${ }^{a}$ School of Chemistry and Molecular Engineering, East China Normal University, 3663 North Zhongshan Road, Shanghai 200062, P. R. China. E-mail: wlu@chem.ecnu.edu. cn; Tel: +86-21-62238771

${ }^{b}$ State Key Laboratory of Fine Chemicals, Dalian University of Technology, Dalian 116024, P. R. China

$\dagger$ Electronic supplementary information (ESI) available. See DOI: 10.1039/c7ra01466j 

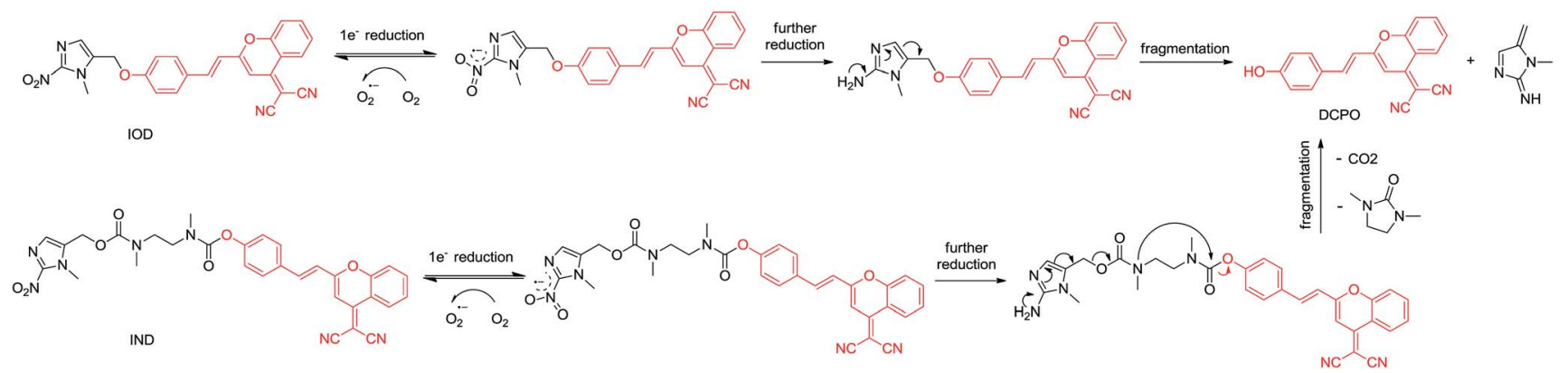

Fig. 2 Proposed mechanism of probes activated via enzymatic metabolism under hypoxic condition.

effective via the bioreduction of nitroreductase, it did not investigate the selectivity between hypoxic and normoxic cell imaging.

In this paper, we proposed new hypoxic fluorescent probes based on (1-methyl-2-nitro-1H-imidazol-5-yl)methanol. The near-infrared fluorescence $\mathrm{OFF}-\mathrm{ON}$ switch could be triggered by nitroimidazole via the transformation of a masked phenol unit to a phenolic hydroxyl group. In normal tissues, no fluorescence was observed via the Förster resonance energy transfer (FRET) mechanism caused by the electron acceptor nitro group. Conversely, in hypoxic solid tumors, the hypoxia-specific nitroto-amino reduction activated the nitroimidazole trigger and generated red-fluorescence (Fig. 2). The ether linkage and biscarbamate linkage were specifically used to connect (1-methyl2-nitro-1 $H$-imidazol-5-yl)methanol and DCPO. The most important of this study was that, two fluorescent probes revealed different properties upon biological evaluation. Probe IOD containing ether linkage was evaluated to be better than probe IND containing bis-carbamate linkage.

\section{Experimental}

\section{Material and methods}

${ }^{1} \mathrm{H}$ and ${ }^{13} \mathrm{C}$ nuclear magnetic resonance (NMR) spectra were recorded on a Bruker DRX-400 MHz spectrometer (400 and 101 $\mathrm{MHz}$, respectively) using $\mathrm{CDCl}_{3}$, or DMSO- $\mathrm{d}_{6}$ as solvents with TMS as an internal standard. Chemical shifts were reported as $\mathrm{d}(\mathrm{ppm})$ and spin-spin coupling constants as $J(\mathrm{~Hz})$ values. The mass spectra (MS) were recorded on a Finnigan MAT-95 mass spectrometer. Melting points were taken on a SGW X-4 melting point apparatus, uncorrected and reported in degrees centigrade. Column chromatography was performed with silica gel (200-300 mesh). UV-vis absorption spectra were recorded on a Varian Cary 100 spectrophotometer. Fluorescence spectra were measured with a Hitachi F-4500 Fluorescence spectrophotometer. Cells were taken photos on an inverted fluorescence microscope (Olympus DP80). The average fluorescence intensity was given by the flow cytometry assay on a Guava easyCyte HT system.

Nitroreductase from Escherichia coli and NADPH were purchased from Sigma-Aldrich. Mouse liver microsomes $(20 \mathrm{mg}$ $\mathrm{mL}^{-1}$ ) were purchased from Corning. Human lung cancer cell line H460, human cervical cancer cell line HeLa and human lung adenocarcinoma cell line A549 were purchased from the Shanghai
Institute of Biochemistry and Cell Biology (Shanghai, China). The cell culture fluid and FBS were purchased from Thermo Fisher Scientific. All of the starting materials are commercially available and were used without further purification.

\section{Ethical statement}

We state that all experiments with live subjects were performed in compliance with the Laboratory Animal Management Regulations of the People's Republic of China and the Three Rs (Replacement, Reduction, and Refinement) strategy of William Russell and Rex Burch, and the Animal Ethical and Welfare Committee of East China Normal University has approved the experiments.

\section{Synthetic procedures}

Compound 1. Compound 1 was synthesized according to the procedure of Duan et al. ${ }^{43}$

Compound 2. To a stirred solution of compound 1 ( $47 \mathrm{mg}$, $0.3 \mathrm{mmol})$ and DMAP (73 $\mathrm{mg}, 0.6 \mathrm{mmol})$ in DCM $(3 \mathrm{~mL})$ was added $\mathrm{TsCl}(69 \mathrm{mg}, 0.36 \mathrm{mmol})$. The reaction was stirred for $4 \mathrm{~h}$ at room temperature. The mixture was concentrated in vacuum and purified by column chromatography on silica gel (heptane $:$ EtOAc $=10: 1)$ to afford compound $2(50 \mathrm{mg}, 95 \%)$ as yellow solid. Mp 96-98 ${ }^{\circ} \mathrm{C} .{ }^{1} \mathrm{H}$ NMR $\left(400 \mathrm{MHz}, \mathrm{CDCl}_{3}\right) \delta 7.19(\mathrm{~s}$, $1 \mathrm{H}), 4.62(\mathrm{~s}, 2 \mathrm{H}), 4.07(\mathrm{~s}, 3 \mathrm{H})$. MS (ESI): $\mathrm{m} / \mathrm{z}$ calcd for $\mathrm{C}_{5} \mathrm{H}_{7} \mathrm{ClN}_{3} \mathrm{O}_{2}[\mathrm{M}+\mathrm{H}]^{+}: 175.01$, found: 175.87 .

Compound 3. To a stirred solution of 4-hydroxybenzaldehyde ( $42 \mathrm{mg}, 0.34 \mathrm{mmol})$ in DMF $(3 \mathrm{~mL})$ was added $\mathrm{K}_{2} \mathrm{CO}_{3}(40 \mathrm{mg}, 0.29 \mathrm{mmol})$ and compound $2(50 \mathrm{mg}, 0.29$ $\mathrm{mmol}$ ). The mixture was stirred overnight at $60^{\circ} \mathrm{C}$. The reaction was quenched with $\mathrm{H}_{2} \mathrm{O}$ and extracted with EtOAc. The combined organic layers were dried over $\mathrm{Na}_{2} \mathrm{SO}_{4}$. Concentration was purified by column chromatography on silica gel (heptane : EtOAc $=1: 1)$ to afford compound $3(65 \mathrm{mg}, 86 \%)$ as yellow solid. Mp 181-183 ${ }^{\circ} \mathrm{C} .{ }^{1} \mathrm{H}$ NMR $\left(400 \mathrm{MHz}, \mathrm{CDCl}_{3}\right) \delta 9.92(\mathrm{~s}, 1 \mathrm{H})$, $7.88(\mathrm{~d}, J=8.4 \mathrm{~Hz}, 2 \mathrm{H}), 7.25(\mathrm{~s}, 1 \mathrm{H}), 7.08(\mathrm{~d}, J=8.4 \mathrm{~Hz}, 2 \mathrm{H}), 5.14$ (s, 2H), 4.07 (s, 3H). ${ }^{13} \mathrm{C}$ NMR (101 MHz, $\left.\mathrm{CDCl}_{3}\right) \delta 190.7,162.6$, 162.2, 132.2, 131.8, 131.1, 129.3, 115.0, 59.7, 36.6, 34.6, 31.5. MS (ESI): $m / z$ calcd for $\mathrm{C}_{12} \mathrm{H}_{12} \mathrm{~N}_{3} \mathrm{O}_{4}[\mathrm{M}+\mathrm{H}]^{+}: 261.08$, found: 261.86 .

Compound 5 (IOD). Compound 3 (30 mg, $11 \mathrm{mmol}$ ) and compound $4(27 \mathrm{mg}, 0.13 \mathrm{mmol})$ was dissolved in acetonitrile $(4 \mathrm{~mL})$, then followed by adding HOAc $(0.2 \mathrm{~mL})$, piperidine 
$(0.2 \mathrm{~mL})$ in sequence. The reaction was stirred overnight at $80{ }^{\circ} \mathrm{C}$, then quenched with water and extracted with DCM. The combined organic layers were dried over $\mathrm{Na}_{2} \mathrm{SO}_{4}$. Concentration was purified by column chromatography on silica gel (DCM : $\mathrm{MeOH}=50: 1$ ) to afford compound 5 (22 $\mathrm{mg}, 44 \%$ ) as red solid. $\mathrm{Mp}>300{ }^{\circ} \mathrm{C} .{ }^{1} \mathrm{H}$ NMR $(400 \mathrm{MHz}, \mathrm{DMSO}) \delta 8.73(\mathrm{~d}, J=$ $8.2 \mathrm{~Hz}, 1 \mathrm{H}), 7.97-7.88(\mathrm{~m}, 1 \mathrm{H}), 7.84-7.69(\mathrm{~m}, 4 \mathrm{H}), 7.65-7.58(\mathrm{~m}$, 1H), 7.45-7.35 (m, 2H), 7.19 (d, $J=8.6 \mathrm{~Hz}, 2 \mathrm{H}), 7.00(\mathrm{~s}, 1 \mathrm{H}), 5.34$ (s, 2H), 3.96 (s, 3H). ${ }^{13} \mathrm{C}$ NMR (101 MHz, DMSO) $\delta$ 159.4, 158.5, 152.9 , 152.0, 146.3, 138.4, 135.4, 133.2, 130.0, 128.6, 128.5, 126.1, 124.6, 119.0, 117.6, 117.3, 117.1, 115.9, 115.6, 106.2, 59.7, 59.3, 34.4. HRMS (ESI): $m / z$ calcd for $\mathrm{C}_{25} \mathrm{H}_{17} \mathrm{~N}_{5} \mathrm{O}_{4} \mathrm{Na}[\mathrm{M}+\mathrm{Na}]^{+}$: 474.1178, found: 474.1177 .

Compound 6. To a stirred solution of compound $1(30 \mathrm{mg}$, $0.19 \mathrm{mmol}$ ) and DIPEA (49 $\mathrm{mg}, 0.38 \mathrm{mmol})$ in DCM $(5 \mathrm{~mL})$ was added bis(4-nitrophenyl)carbonate $(64 \mathrm{mg}, 0.21 \mathrm{mmol})$. The reaction was stirred for $4 \mathrm{~h}$ at room temperature, then was added $N, N^{\prime}$-dimethyl- $N$-tritylethane-1,2-diamine (94 mg, 0.29 $\mathrm{mmol})$. The mixture was stirred for another $1 \mathrm{~h}$. Then the solution was washed with $\mathrm{Na}_{2} \mathrm{CO}_{3}$ and extracted with DCM. The combined organic layers were dried over $\mathrm{Na}_{2} \mathrm{SO}_{4}$. Concentration was purified by column chromatography on silica gel (heptane $:$ EtOAc $=2: 1)$ to afford compound $6(88 \mathrm{mg}, 91 \%)$ as yellow solid. Mp 100-102 ${ }^{\circ} \mathrm{C} .{ }^{1} \mathrm{H}$ NMR (400 MHz, $\left.\mathrm{CDCl}_{3}\right) \delta$ 7.50-7.37 (m, 6H), 7.26-7.19 (m, 6H), 7.18-7.11 (m, 3H), 7.08 (s, 1H), 5.19$5.01(\mathrm{~m}, 2 \mathrm{H}), 4.05-3.62(\mathrm{~m}, 3 \mathrm{H}), 3.56-3.37$ (m, 2H), 3.13-2.89 (m, 3H), 2.38-2.18 (m, 2H), 2.18-2.05 (m, 3H). MS (ESI): $m / z$ calcd for $\mathrm{C}_{29} \mathrm{H}_{32} \mathrm{~N}_{5} \mathrm{O}_{4}[\mathrm{M}+\mathrm{H}]^{+}: 514.24$, found: 514.37 .

Compound 7. To a stirred solution of compound 6 (51 mg, $0.1 \mathrm{mmol})$ in DCM $(2 \mathrm{~mL})$ was added trifluoroacetic acid (0.2 $\mathrm{mL}$ ). The reaction was stirred for $1 \mathrm{~h}$ at room temperature, and concentrated in vacuum to produce the crude product of compound 7, which was used in the next step without purification.

Compound 9. Under $\mathrm{N}_{2}$ atmosphere, to a stirred solution of compound 8 (31 mg, $0.1 \mathrm{mmol}$ ) and triphosgene (15 mg, 0.05 $\mathrm{mmol})$ in dry DCM $(10 \mathrm{~mL})$ was added DIPEA (39 mg, $0.3 \mathrm{mmol}$ ) dropwise at $0{ }^{\circ} \mathrm{C}$. Then the reaction was stirred at room temperature overnight and put into next step without purification.

Compound 10 (IND). To a stirred solution of crude compound 7 in DCM ( $2 \mathrm{~mL}$ ) was added appropriate DIPEA to keep $\mathrm{pH}$ among 7-8. Then the solution of compound 9 was added into the reaction and stirred at room temperature for $2 \mathrm{~h}$. The mixture was concentrated in vacuum and purified by column chromatography on silica gel (DCM : $\mathrm{MeOH}=30: 1$ ) to afford compound $10(24 \mathrm{mg}, 39 \%)$ as red solid. $\mathrm{Mp}>$ $300{ }^{\circ} \mathrm{C}$. ${ }^{1} \mathrm{H} \mathrm{NMR}\left(400 \mathrm{MHz}, \mathrm{CDCl}_{3}\right) \delta{ }^{1} \mathrm{H} \mathrm{NMR}(400 \mathrm{MHz}$, $\left.\mathrm{CDCl}_{3}\right) \delta 8.92(\mathrm{~d}, J=8.3 \mathrm{~Hz}, 1 \mathrm{H}), 7.79-7.71(\mathrm{~m}, 1 \mathrm{H}), 7.66-7.51$ $(\mathrm{m}, 4 \mathrm{H}), 7.50-7.41(\mathrm{~m}, 1 \mathrm{H}), 7.24-6.99(\mathrm{~m}, 3 \mathrm{H}), 6.88(\mathrm{~s}, 1 \mathrm{H})$, 6.82-6.73 (m, 1H), 5.23-5.08 (m, 2H), 4.10-3.90 (m, 3H), 3.70$3.42(\mathrm{~m}, 4 \mathrm{H}), 3.20-2.87(\mathrm{~m}, 6 \mathrm{H}) .{ }^{13} \mathrm{C} \mathrm{NMR}\left(101 \mathrm{MHz}, \mathrm{CDCl}_{3}\right)$ $\delta$ 157.4, 155.6, 154.6, 154.1, 152.9, 152.4, 146.2, 137.9, 134.8, 123.0, 129.7, 129.5, 129.1, 129.04, 126.1, 125.9, 122.3, 118.8, 117.9, 116.9, 115.7, 107.0, 62.9, 56.0, 47.5, 34.4, 29.8. HRMS (ESI): $m / z$ calcd for $\mathrm{C}_{31} \mathrm{H}_{27} \mathrm{~N}_{7} \mathrm{O}_{7} \mathrm{Na}[\mathrm{M}+\mathrm{Na}]^{+}: 632.1870$, found: 632.1899 .

\section{General HPLC method}

HPLC analysis was performed at room temperature using a Diamonsil $\mathrm{C}_{18}(250 \mathrm{~mm} \times 4.6 \mathrm{~mm})$ and a mobile phase gradient from $5 \% \mathrm{CH}_{3} \mathrm{CN} /$ buffer $\left(0.1 \% \mathrm{TFA} / \mathrm{H}_{2} \mathrm{O}\right)$ to $70 \%$ $\mathrm{CH}_{3} \mathrm{CN} /$ buffer $\left(0.1 \% \mathrm{TFA} / \mathrm{H}_{2} \mathrm{O}\right)$ for $5 \mathrm{~min}, 70 \% \mathrm{CH}_{3} \mathrm{CN} /$ buffer $\left(0.1 \% \mathrm{TFA} / \mathrm{H}_{2} \mathrm{O}\right)$ to $95 \% \mathrm{CH}_{3} \mathrm{CN} /$ buffer $\left(0.1 \% \mathrm{TFA} / \mathrm{H}_{2} \mathrm{O}\right)$ for $10 \mathrm{~min}, 95 \% \mathrm{CH}_{3} \mathrm{CN} /$ buffer $\left(0.1 \% \mathrm{TFA} / \mathrm{H}_{2} \mathrm{O}\right)$ for $5 \mathrm{~min}$, a flow

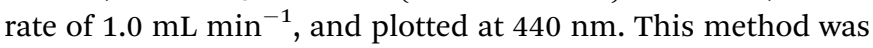
used to determine the purity for the tested compounds, and also used in stability studies.

\section{General method for nitroreductase assay and cytochrome P450 metabolism assay}

The probe measurements were made in $10 \mathrm{mM}$ PBS ( $\mathrm{pH} 7.4,1 \%$ DMSO). The incubation mixtures of test probes with nitroreductase contained the following at the indicated final concentrations: $10 \mu \mathrm{M}$ test compound, nitroreductase (50 $\mu \mathrm{g}$ $\mathrm{mL}^{-1}$ ) and $1 \mathrm{mM}$ NADPH. The incubation mixtures of test probes with mouse liver microsomes contained the following at the indicated final concentrations: $25 \mu \mathrm{M}$ test compound, $5 \mathrm{mM}$ $\mathrm{MgCl}_{2}$, mouse liver microsomes $\left(50 \mu \mathrm{g} \mathrm{mL}{ }^{-1}\right)$ and $1 \mathrm{mM}$ NADPH. The mixtures were incubated at $37{ }^{\circ} \mathrm{C}$. At different time, $100 \mu \mathrm{L}$ reaction mixture was quenched by $100 \mu \mathrm{L}$ cold methanol. The samples were centrifuged at $4{ }^{\circ} \mathrm{C}$ for $5 \mathrm{~min}$ at $12000 \mathrm{rpm}$. The supernatant was transferred to a vial for analysis using HPLC.

\section{Cell culture and imaging}

H460, HeLa, A549 were cultured in RPMI 1640 medium, DMEM medium, F12 medium, supplemented with 10\% fetal bovine serum and $1 \%$ penicillin streptomycin in a $5 \% \mathrm{CO}_{2}$ humidified environment at $37{ }^{\circ} \mathrm{C}$. Cells were seeded in 96-well plates and incubated for $24 \mathrm{~h}$. The next day, test probes in DMSO were diluted in medium with final concentration of $10 \mu \mathrm{M}(1 \%$ DMSO). The cells in the hypoxia treatment group were incubated for $24 \mathrm{~h}$ in the anaerobic chamber flushed with a certified anaerobic gas mixture ( $94 \% \mathrm{~N}_{2} / 5 \% \mathrm{CO}_{2} / 1 \% \mathrm{O}_{2}$; Thermo). The cells in the air treatment group were incubated for $24 \mathrm{~h}$ in standard cell-culture incubator. After appropriate time of treatment with test compounds, the cells were washed with 200 $\mu \mathrm{L}$ PBS three times and fixed with $4 \%$ paraformaldehyde. Finally, $100 \mu \mathrm{L}$ of PBS was added and the cells were visualized on an inverted fluorescence microscope (Olympus DP80) with green exciting light. The fluorescence images were taken under a $20 \times$ objective. The average fluorescence intensity was detected at $661 \mathrm{~nm}$ and excited at $640 \mathrm{~nm}$ by the flow cytometry assay on a Guava easyCyte HT system.

\section{Results and discussion}

\section{Chemistry}

Compound 1 was reacted with TsCl in the presence of DMAP to prepare compound 2 . Then, 4-hydroxybenzaldehyde was reacted with compound 2 in $\mathrm{K}_{2} \mathrm{CO}_{3} / \mathrm{DMF}$ to afford compound 3 . Compounds 3 and 4 were refluxed in acetonitrile with HOAc and piperidine to produce compound 5 (IOD) with $36 \%$ overall 


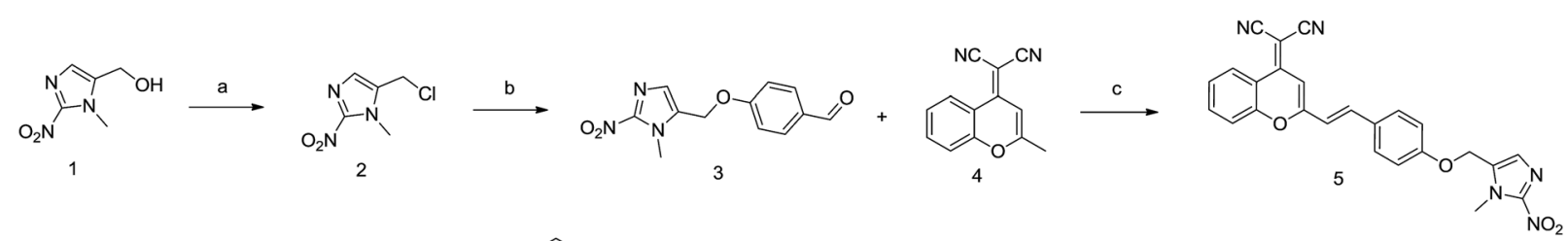<smiles></smiles><smiles>N#CC(C#N)=C1C=C(/C=C/c2ccc(O)cc2)Oc2ccccc21</smiles><smiles>N#CC(C#N)=C1C=C(C=Cc2ccc(OC(=O)Cl)cc2)Oc2ccccc21</smiles><smiles>CN(CCN(C)C(=O)Oc1ccc(/C=C/C2=CC(=C(C#N)C#N)c3ccccc3O2)cc1)C(=O)OCc1cnc([N+](=O)[O-])n1C</smiles>

Scheme 1 Reagents and conditions: (a) TsCl, DMAP, DCM; (b) $\mathrm{K}_{2} \mathrm{CO}_{3}$, DMF; (c) HOAc, piperidine, acetonitrile; (d) bis(4-nitrophenyl)carbonate, $N, N^{\prime}$-dimethyl-N-tritylethane-1,2-diamine, DIPEA, DCM; (e) 10\% TFA/DCM; (f) triphosgene, DIPEA, DCM; (g) DIPEA, DCM.

yield. On the other hand, compound 1 was treated with bis(4nitrophenyl)carbonate followed by the addition of $N$-trityl- $N, N^{\prime}$ dimethylethylenediamine to produce compound $\mathbf{6}$. The trityl protecting group was removed in $10 \%$ TFA/DCM to afford compound 7. DCPO was reacted with triphosgene/DIPEA, followed by the addition of the solution of compound 7 to synthesize compound 10 (IND) with $35 \%$ overall yield (Scheme 1).

\section{Optical properties of probes}

We tested the optical properties of the probe (IOD/IND) in PBS buffer (10 mM, pH 7.4, 50\% DMSO). The main absorption peak of DCPO appeared at $560 \mathrm{~nm}$ while low absorption peaks of IOD/IND were observed at $560 \mathrm{~nm}$ (Fig. 3). As expected, the fluorescence of the probe was eliminated when the phenol moiety was masked with nitroimidazole.

\section{In vitro nitroreductase assay}

We proposed that both IOD and IND could be reduced to the original fluorescent probe DCPO. To testify whether the probes could be activated and fragmented, nitroreductase (NTR) from Escherichia coli was used. The probes dissolved in PBS (5 $\mu \mathrm{M}$, PBS

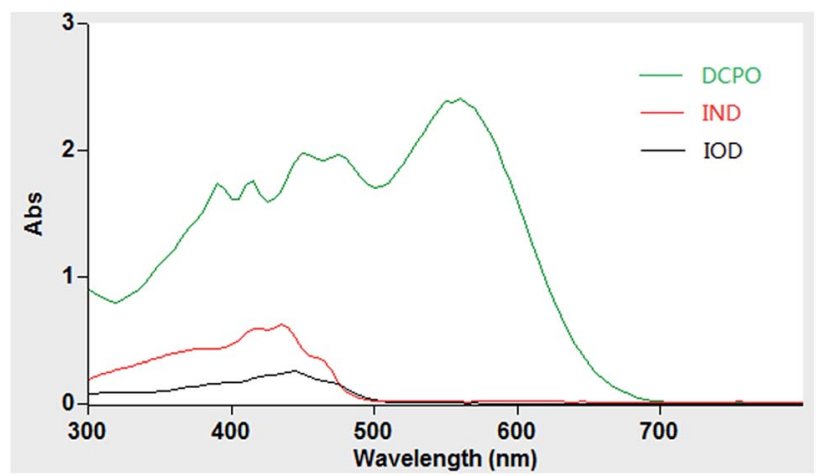

Fig. 3 Absorption spectra of DCPO, IOD and IND, $25 \mu \mathrm{M}$ in PBS buffer (10 mM, pH 7.4, 50\% DMSO). buffer with $1 \%$ DMSO) were incubated with nitroreductase (50 $\mu \mathrm{g}$ $\left.\mathrm{mL}^{-1}\right)$ and NADPH $\left(1 \mu \mathrm{mol} \mathrm{mL}^{-1}\right)$ at $37{ }^{\circ} \mathrm{C}$. The reduction processes of IOD and IND were monitored through HPLC (Fig. 4). However, the two probes revealed different properties. The results indicated that IND was completely reduced and almost converted to DCPO at $15 \mathrm{~min}$. On the other hand, $42 \%$ of IOD was still remaining at $15 \mathrm{~min}$. We supposed that both probes underwent the bioreductive processes, as we proposed. Due to the reversible reaction in the first step under the normoxic condition, it was more reasonable to have $42 \%$ of IOD remaining.

\section{In vitro cytochrome $\mathbf{P 4 5 0}$ metabolism assay}

Though the probes could be reduced by bioreductase, it was necessary to testify whether the probes could be stable in the presence of other enzymes. As we know, many prodrugs and

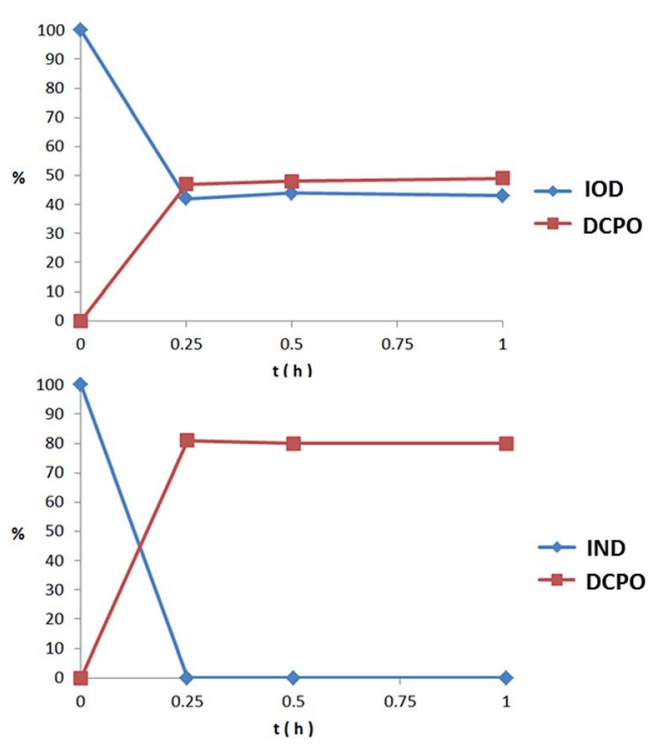

Fig. 4 Percent of probe remaining and DCPO releasing in $1 \mathrm{~h}$ incubation with nitroreductase $\left(50 \mu \mathrm{g} \mathrm{mL}^{-1}\right)$ and NADPH $\left(1 \mu \mathrm{mol} \mathrm{mL}{ }^{-1}\right)$ at $37^{\circ} \mathrm{C}$. 
Table 1 In vitro stability of probes

\begin{tabular}{llllll}
\hline & $\mathrm{NTR}^{a}$ & & & $\mathrm{MLM}^{b}$ & \\
\cline { 2 - 3 } \cline { 5 - 6 } & $\begin{array}{l}\text { Compound } \\
\text { remaining }\end{array}$ & $\begin{array}{l}\text { DCPO } \\
\text { release }\end{array}$ & & $\begin{array}{l}\text { Compound } \\
\text { remaining }\end{array}$ & $\begin{array}{l}\text { DCPO } \\
\text { release }\end{array}$ \\
\hline IOD & 42 & 47 & & 48 & 43 \\
IND & 0 & 81 & 2 & 30
\end{tabular}

${ }^{a}$ Percent of probe remaining and DCPO releasing in $1 \mathrm{~h}$ of incubation with nitroreductase $\left(50 \mu \mathrm{g} \mathrm{mL}^{-1}\right)$ and NADPH $\left(1 \mu \mathrm{mol} \mathrm{mL}^{-1}\right)$ at $37^{\circ} \mathrm{C}$. ${ }^{b}$ Percent of probe remaining and DCPO releasing in $24 \mathrm{~h}$ of incubation with mouse liver microsomes $\left(50 \mu \mathrm{g} \mathrm{mL}^{-1}\right)$ and NADPH $\left(1 \mu \mathrm{mol} \mathrm{mL} L^{-1}\right)$ at $37^{\circ} \mathrm{C}$.

probes undergo oxidation and reduction metabolism by cytochrome P450. Cytochrome P450, which is the main component of animals' liver microsomal enzyme, was used to test the metabolism of the probes. Mouse liver microsomes $\left(50 \mu \mathrm{g} \mathrm{mL}^{-1}\right)$ and NADPH $\left(1 \mu \mathrm{mol} \mathrm{mL} \mathrm{m}^{-1}\right)$ were added to the IOD/IND solution (25 $\mu \mathrm{M}$, PBS buffer with 1\% DMSO) and incubated at $37{ }^{\circ} \mathrm{C}$ for $24 \mathrm{~h}$. The results were detected using HPLC (Table 1). The quantity of IOD remaining and DCPO released in the mouse liver microsome assay was similar to that in the nitroreductase assay. However, IND showed a distinct difference in DCPO release. The HPLC results indicated that IND was converted to other DCPO derivatives and the quantity of DCPO released was much lower. The fluorescence emissions of the probes after incubation with mouse liver microsomes for $24 \mathrm{~h}$ are shown in Fig. 5, which also indicates that IOD had a stronger emission than IND. We hypothesized that IOD underwent bioreductive metabolism, as we proposed previously. However, IND underwent a more complicated metabolic process, maybe because the biscarbamate linkage could be a substrate for other enzymes besides the reductase in cytochrome $\mathrm{P} 450$.

\section{Fluorescence imaging in H460, HeLa, A549 cell lines}

The probes were evaluated under normoxic and hypoxic (94\% $\mathrm{N}_{2} / 5 \% \mathrm{CO}_{2} / 1 \% \mathrm{O}_{2}$ ) conditions using $\mathrm{H} 460$, HeLa and A549 cell

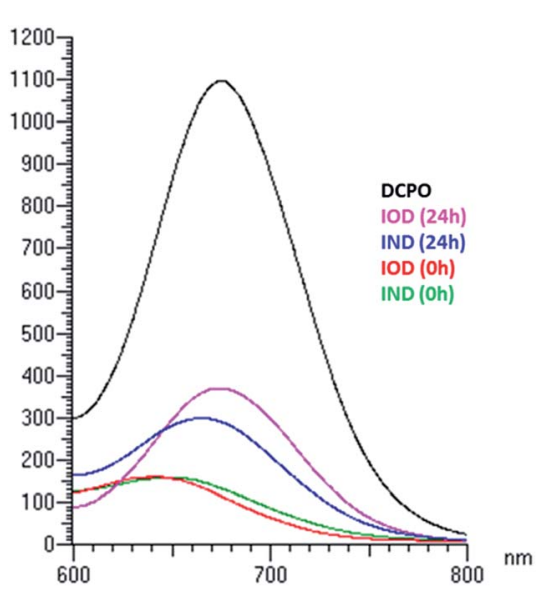

Fig. 5 Emission spectra of probes $(25 \mu \mathrm{M})$ excited at $560 \mathrm{~nm}$ after $24 \mathrm{~h}$ incubation with mouse liver microsomes $\left(50 \mu \mathrm{g} \mathrm{mL}^{-1}\right)$ and NADPH (1 $\mu \mathrm{mol} \mathrm{mL}{ }^{-1}$ ) at $37^{\circ} \mathrm{C}$. lines. The probes IOD and IND $(10 \mu \mathrm{M}, 1 \% \mathrm{DMSO})$ were cocultivated with cells at $37{ }^{\circ} \mathrm{C}$ under hypoxic and normoxic conditions for different lengths of time.

As shown in Fig. 6, time-dependent fluorescence enhancement was observed under hypoxic conditions, while fluorescence changes under normoxic conditions were not as obvious as hypoxic conditions. In each cell line, probe IOD was observed

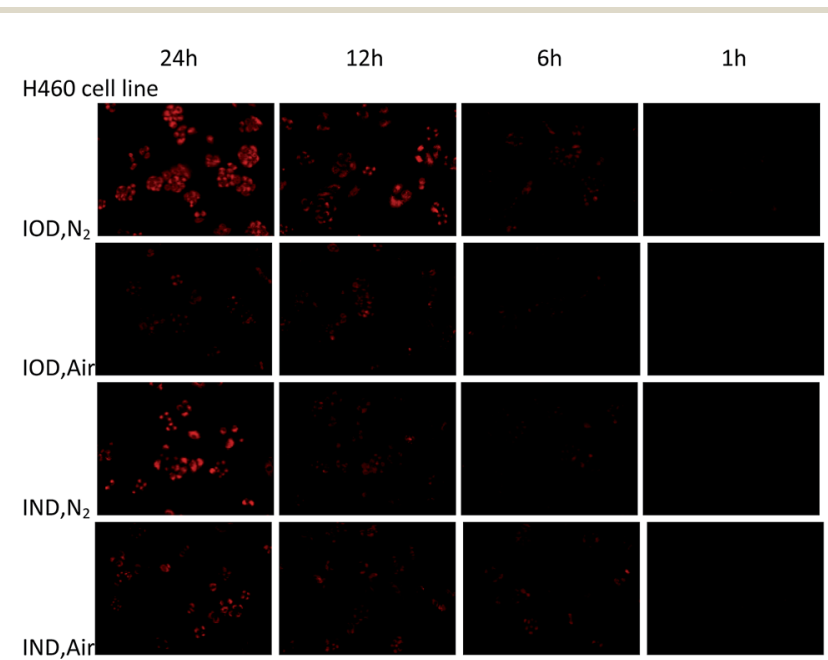

HeLa cell line
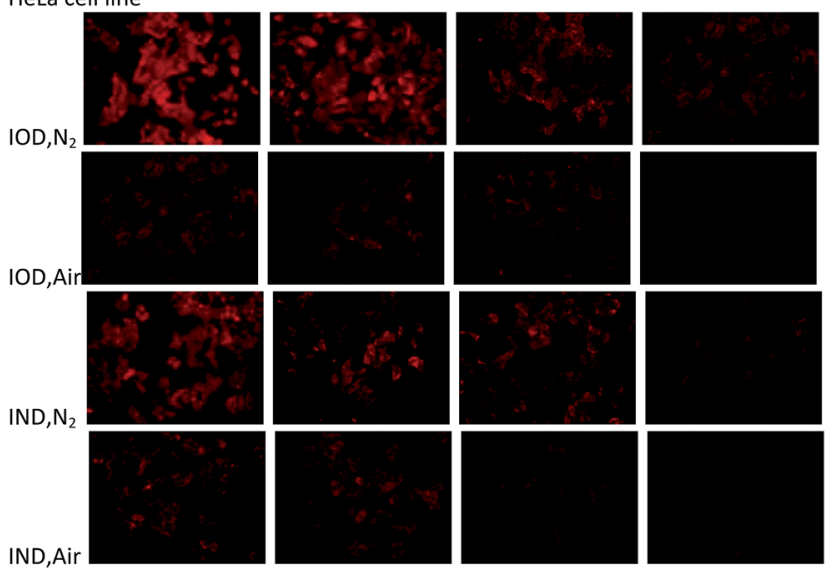

A549 cell line

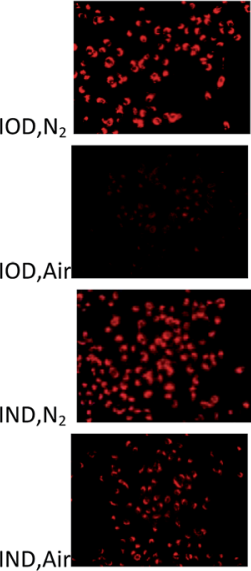

$24 h$
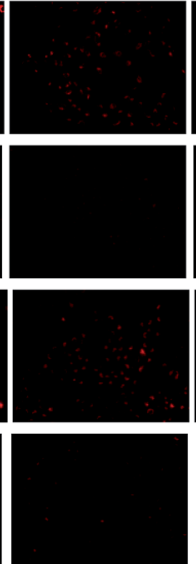

$12 \mathrm{~h}$
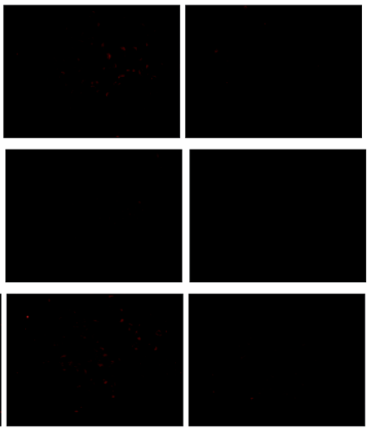

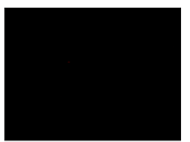

$6 h$

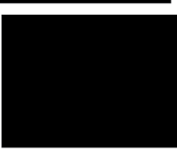

$1 \mathrm{~h}$
Fig. 6 Fluorescence field microphotographs of H460, HeLa and H460 cells incubated with $10 \mu \mathrm{M}$ probe under normoxic and hypoxic condition $\left(94 \% \mathrm{~N}_{2} / 5 \% \mathrm{CO}_{2} / 1 \% \mathrm{O}_{2}\right)$ for different time. 


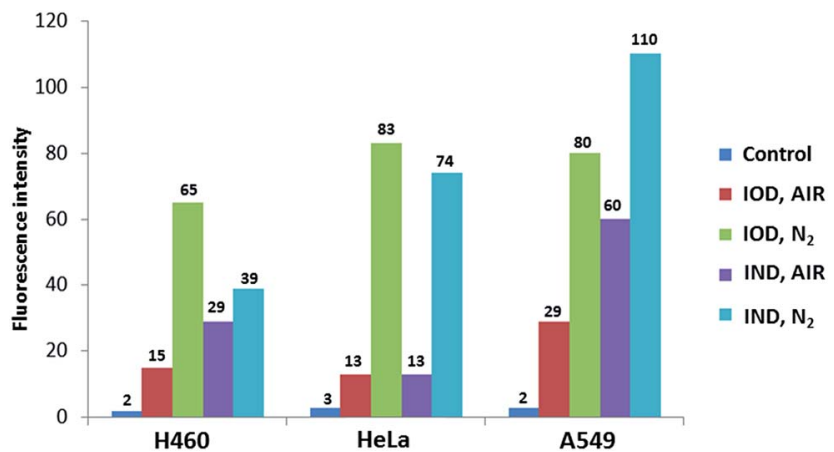

Fig. 7 The average fluorescence intensity of H460, HeLa, A549 cells detected at $661 \mathrm{~nm}$ and excited at $640 \mathrm{~nm}$.

to have greater difference between hypoxic and normoxic cells. The average fluorescence intensity after $24 \mathrm{~h}$ incubation was given by the flow cytometry assay on a Guava easyCyte HT system (Fig. 7). The quantified results indicated that, probe IOD had a higher hypoxia selectivity ratio than IND in each cell line.

The cytotoxicity of probes was investigated on three cell lines. The results indicated that, the probes had no obvious inhibition towards three cell lines in both hypoxic and normoxic condition (Fig. S2 $\dagger$ ).

\section{Conclusions}

In this study, we synthesized two probes based on (1-methyl-2nitro- $1 H$-imidazol-5-yl)methanol and DCPO. Biological evaluation indicated that different linkages revealed distinctly different results. Probe IOD with an ether linkage was demonstrated to be able to release DCPO via metabolism by nitroreductase and cytochrome $\mathbf{P} 450$. However, probe IND with a biscarbamate linkage may be a substrate to enzymes beyond the reductase in cytochrome $\mathbf{P} 450$. The hypoxia selectivity ratio of IOD was evaluated to be higher than that of IND on H460, HeLa and A549 cell lines. In conclusion, the probe IOD was considered to be a promising hypoxia-selective fluorescent probe.

\section{Acknowledgements}

The authors are grateful for the financial support from the State Key Laboratory of Fine Chemicals, Dalian University of Technology (KF1517).

\section{Notes and references}

1 J. M. Brown, Cancer Biol. Ther., 2002, 1, 453-458.

2 W. R. Wilson and M. P. Hay, Nat. Rev. Cancer, 2011, 11, 393410.

3 R. A. Cairns, I. S. Harris and T. W. Mak, Nat. Rev. Cancer, 2011, 11, 85-95.

4 T. G. Graeber, C. Osmanian, T. Jacks, D. E. Housman, C. J. Koch, S. W. Lowe and A. J. Giaccia, Nature, 1996, 379, 88-91.
5 J. T. Erler, C. J. Cawthorne, K. J. Williams, M. Koritzinsky, B. G. Wouters, C. Wilson, C. Miller, C. Demonacos, I. J. Stratford and C. Dive, Mol. Cell. Biol., 2004, 24, 28752889.

6 K. M. Rouschop, B. T. Van, L. Dubois, H. Niessen, J. Bussink, K. Savelkouls, T. Keulers, H. Mujcic, W. Landuyt, J. W. Voncken, P. Lambin, A. J. Kogel, M. Koritzinsky and B. G. Wouters, J. Clin. Invest., 2010, 120, 127-141.

7 Y. Wang and M. Ohh, J. Cell. Mol. Med., 2010, 14, 496-503.

8 R. D. Guzy, B. Hoyos, E. Robin, H. Chen, L. P. Liu, K. D. Mansfield, M. C. Simon, U. Hammerling and P. T. Schumacker, Cell Metab., 2005, 1, 401-408.

9 J. M. Brown and W. R. Wilson, Nat. Rev. Cancer, 2004, 4, 437447.

10 G. O. Ahn and M. Brown, Front. Biosci., 2007, 12, 3483-3501.

11 R. M. Phillips, Cancer Chemother. Pharmacol., 2016, 77, 441457.

12 T. Thambi, J. H. Park and D. S. Lee, Chem. Commun., 2016, 52, 8492-8500.

13 A. J. Lin, L. A. Cosby, C. W. Shansky and A. C. Sartorelli, J. Med. Chem., 1973, 15, 1247-1252.

14 S. R. McKeown, R. L. Cowen and K. J. Williams, Clin. Oncol., 2007, 19, 427-442.

15 R. P. Mason and J. L. Holtzman, Biochem. Biophys. Res. Commun., 1975, 67, 1267-1274.

16 E. Nieto, M. Delgado, M. Sobrado, M. L. Ceballos, R. Alajarín, L. G. García, J. Kelly, I. Lizasoain and M. A. Pozo, Eur. J. Med. Chem., 2015, 101, 604-615.

17 K. L. Bennewith, J. A. Raleigh and R. E. Durand, Cancer Res., 2002, 62, 6827-6830.

18 S. M. Evans, K. D. Judy, I. Dunphy, W. T. Jenkins, P. T. Nelson, R. Collins, E. P. Wileyto, K. Jenkins, S. M. Hahn, C. W. Stevens, A. R. Judkins, P. Phillips, B. Geoerger and C. J. Koch, Cancer Res., 2004, 64, 1886-1892.

19 J. G. Rajendran and D. A. Mankoff, J. Nucl. Med., 2007, 48, 855-856.

20 Z. Guo, S. Park, J. Yoon and I. Shin, Chem. Soc. Rev., 2014, 43, 16-29.

21 A. R. Lippert, G. C. Van de Bittner and C. J. Chang, Acc. Chem. Res., 2011, 44, 793-804.

22 Y. Yang, Q. Zhao, W. Feng and F. Li, Chem. Rev., 2012, 113, 192-270.

23 S. A. Hilderbrand and R. Weissleder, Curr. Opin. Chem. Biol., 2010, 14, 71-79.

24 G. Bazar, V. Eles, Z. Kovacs, R. Romvari and A. Szabo, Talanta, 2016, 155, 202-211.

25 R. Risoluti, S. Materazzi, A. Gregori and L. Ripani, Talanta, 2016, 153, 407-413.

26 L. He, B. Dong, Y. Liu and W. Lin, Chem. Soc. Rev., 2016, 45, 6449-6461.

27 X. Chen, Y. Zhou, X. Peng and J. Yoon, Chem. Soc. Rev., 2010, 39, 2120-2135.

28 J. Du, M. Hu, J. Fan and X. Peng, Chem. Soc. Rev., 2012, 41, 4511-4535.

29 X. Zhang, L. Zhang, Y. Liu, B. Bao, Y. Zang, J. Li and W. Lu, Tetrahedron, 2015, 71, 4842-4845. 
30 B. Bao, Y. Liu, L. Wang and W. Lu, RSC Adv., 2016, 6, 6954069545.

31 S. Chen, Y. Fang, Q. Zhu, W. Zhang, X. Zhang and W. Lu, RSC Adv., 2016, 6, 81894-81901.

32 Z. Lu, J. Wu, W. Liu, G. Zhang and P. Wang, RSC Adv., 2016, 6, 32046-32051.

33 P. Wang, K. Wang, D. Chen, Y. Mao and Y. Gu, RSC Adv., 2015, 5, 85957-85963.

34 J. Cao, C. Zhao and W. Zhu, Tetrahedron Lett., 2012, 53, 21072110.

35 T. Guo, L. Cui, J. Shen, W. Zhu, Y. Xu and X. Qian, Chem. Commun., 2013, 49, 10820-10822.

36 J. Zhou, W. Shi, L. Li, Q. Gong, X. Wu, X. Li and H. Ma, Chem.-Asian J., 2016, 11, 2719-2724.

37 Q. Cai, T. Yu, W. Zhu, Y. Xu and X. Qian, Chem. Commun., 2015, 51, 14739-14741.
38 J. Rao and A. Khan, J. Am. Chem. Soc., 2013, 135, 1405614059.

39 J. Rao, C. Hottinger and A. Khan, J. Am. Chem. Soc., 2014, 136, 5872-5875.

40 K. Okuda, Y. Okabe, T. Kadonosono, T. Ueno, B. G. M. Youssif, S. K. Kondoh and H. Nagasawa, Bioconjugate Chem., 2012, 23, 324-329.

41 Q. Lin, C. Bao, Y. Yang, Q. Liang, D. Zhang, S. Cheng and L. Zhu, Adv. Mater., 2013, 25, 1981-1986.

42 K. Xu, F. Wang, X. Pan, R. Liu, J. Ma, F. Kong and B. Tang, Chem. Commun., 2013, 49, 2554-2556.

43 J. X. Duan, H. Jiao, J. Kaizerman, T. Stanton, J. W. Evans, L. Lan, G. Lorente, M. Banica, D. Jung, J. Wang, H. Ma, X. Li, Z. Yang, R. M. Hoffman, W. S. Ammons, C. P. Hart and M. Matteucci, J. Med. Chem., 2008, 51, 2412-2420.

44 J. B. Grimm, T. D. Gruber, G. Ortiz, T. A. Brown and L. D. Lavis, Bioconjugate Chem., 2016, 27, 474-480. 